\title{
Metabolomic Analysis of Diapausing and Noni-diapausing Larvae of the European Corn Borer Ostrinia nubilalis (Hbn.) (Lepidoptera: Crambidae)
}

\author{
Jelena Purać, ${ }^{1, *}$ Danijela Kojić, ${ }^{1}$ Željko D. Popović, ${ }^{1}$ Elvira Vukašinović, ${ }^{1}$ \\ Stefano Tiziani, ${ }^{2}$ Ulrich L. Günther ${ }^{3}$ and Gordana Grubor-Lajšić ${ }^{1}$ \\ ${ }^{1}$ Department of Biology and Ecology, Faculty of Sciences, University of Novi Sad, Trg Dositeja Obradovića 3, \\ 21000 Novi Sad, Serbia, \\ ${ }^{2}$ Department of Nutritional Sciences, Dell Pediatric Research Institute, University of Texas at Austin, \\ 1400 Barbara Jordan Blvd, Austin, Texas 78723, United States, \\ ${ }^{3}$ The Henry Wellcome Building for Biomolecular NMR Spectroscopy, School of Cancer Sciences, \\ University of Birmingham, Edgbaston, Birmingham, B15 2TT, United Kingdom \\ * Corresponding author: E-mail: jelena.purac@dbe.uns.ac.rs \\ Tel: +381214852797
}

Received: 22-01-2015

\begin{abstract}
In this study, an ${ }^{1} \mathrm{H}$-NMR -based metabolomic approach was used to investigate the biochemical mechanisms of diapause and cold hardiness in diapausing larvae of the European corn borer Ostrinia nubilalis. Metabolomic patterns in polar hemolymph extracts from non-diapausing and diapausing larvae of $O$. nubilalis were compared. Analysis indicated 13 metabolites: 7 amino acids, glycerol, acetate, citrate, succinate, lactate and putrescine. Results show that diapausing larvae display different metabolomic patterns compared to active non-diapausing larvae, with predominant metabolites identified as glycerol, proline and alanine. In specific diapausing larvae initially kept at $5{ }^{\circ} \mathrm{C}$ then gradually chilled to $-3{ }^{\circ} \mathrm{C}$ and $-16{ }^{\circ} \mathrm{C}$, alanine, glycerol and acetate were predominant metabolites. ${ }^{1} \mathrm{H}$-NMR spectroscopy provides new insight into the metabolomic patterns associated with cold resistance and diapause in $O$. nubilalis larvae, suggesting distinct metabolomes function in actively developing and diapausing larvae.
\end{abstract}

Keywords: Cold hardiness, NMR spectroscopy, amino acids, polyamines, glycerol, intermediary metabolites

\section{Introduction}

Organisms, such as insects have evolved various mechanisms to adapt to adverse environmental conditions. As part of a general survival strategy, many insects have the ability to suppress basal metabolic rates and enter a hypometabolic or dormant state known as diapause. Besides insects, diapause is common in invertebrates such as rotifers, nematodes, earthworms, crustaceans and terrestrial gastropods. ${ }^{1}$

Diapause is a genetically determined, obligatory or facultative developmental arrest that can occur at the embryonic, larval, pupal, or adult stage of a given species. It is a dynamic process consisting of several distinct phases each characterized by a particular set of biochemical and physiological changes. ${ }^{1}$ Several comprehensive reviews have been published on the environmental, ${ }^{2,3}$ hormonal and molecular regulation of diapause. ${ }^{4-7}$ During diapause overall metabolism is depressed, energy production and consumption processes are adjusted, and gene expression and biochemical pathways are diverted toward synthesis of protective molecules.

Many insects of temperate regions develop cold hardiness during winter diapause. ${ }^{8-10}$ Several eco-physiological and biochemical studies have been conducted to improve our understanding of the cellular mechanisms of cold hardening process during the hypometabolic state. ${ }^{11,12}$ The main function of metabolism during periods of cold accli- 
mation is biosynthesis of low molecular weight organic solutes such as polyols and sugars that depress the body's supercooling point (cryoprotectants), while stabilizing proteins and cellular membranes. ${ }^{13,14}$ Story and Story summarize recent research on the biochemical adaptations associated with insect cold hardiness, including: regulation of cryoprotectant biosynthesis, mechanisms of metabolic rate depression, the role of aquaporins, and cell preservation strategies (chaperones, antioxidant defence systems, metal binding proteins and mitochondrial suppression). ${ }^{15}$

Most studies on the molecular basis of insect cold hardiness conducted to date have been based on the level of the genome, transcriptome and proteome. ${ }^{15-18}$ Despite significant progress in this area, many aspects of the metabolic adaptations underlying diapause and cold hardiness remain undiscovered, especially in non-model organisms. We propose that a metabolomic approach could provide insight into the metabolite composition underlying adaptations in response to unfavourable environmental conditions, such as low temperature. Since comprehensive analysis of the metabolites present in an organism or cell is crucial to understanding cellular processes and function, reports describing metabolomic approaches for studying insect biochemistry have been gradually increasing over the past several years. ${ }^{19-25}$ Metabolomics as a part of systems biology can reveal the unique fingerprint of low molecular weight metabolites within a biological sample that are characteristic for a specific physiological state. ${ }^{26,27}$

In the present study, we analyzed metabolomic profiles in diapausing larvae of the European corn borer Ostrinia nubilalis (Lepidoptera: Crambidae), a maize pest species of Eurasia and North America. O. nubilalis overwinters as a diapausing $5^{\text {th }}$ instar larvae mostly in corn stalks. Cold hardiness in this species is tightly linked with diapause. During diapause, larvae gradually accumulate glycerol and, to less extent, trehalose in hemolymph and become cold tolerant with a supercooling point of approximately $-20{ }^{\circ} \mathrm{C} .{ }^{28}$ To investigate the role of altered overall metabolic activity in cold hardening larvae of $O$. nubilalis, in the present study we compare the metabolomic patterns of diapause and non-diapause larvae using high-resolution ${ }^{1} \mathrm{H}$ nuclear magnetic resonance (NMR) spectroscopy with multivariate analysis. In addition, we have also examined the metabolomic responses in diapausing larvae maintained at $5{ }^{\circ} \mathrm{C}$ and subsequently exposed to $-3{ }^{\circ} \mathrm{C}$ and $-16{ }^{\circ} \mathrm{C}$ for two weeks. To our knowledge, this is the first report describing application of NMR spectroscopy to provide insight into mechanisms of cold resistance and diapause in Ostrinia nubilalis.

\section{Experimental}

\section{1. Materials and Methods}

Specimens of non-diapausing larvae of Ostrinia nubilalis were collected in July, while diapausing larvae were collected in October from maize plants from fields in Vojvodina Province, Serbia. Diapausing larvae were kept in a laboratory at $5{ }^{\circ} \mathrm{C}$ and $70 \%$ relative humidity for a week and then divided into two groups. The first was kept at $5{ }^{\circ} \mathrm{C}$ for two weeks and the second was divided into two subgroups by gradual exposure to temperatures of $-3{ }^{\circ} \mathrm{C}$ and $-16{ }^{\circ} \mathrm{C}$ (cooling rate $\sim 3{ }^{\circ} \mathrm{C}$ per day). Larvae were kept at these temperatures for two weeks. Following this treatment, survival was $100 \%$ and samples were collected. Analysis included five replicate pools. For each pool $150 \mu \mathrm{l}$ of hemolymph was sampled and merged from 10-12 animals by cutting the prolegs of larvae and squeezing hemolymph into $1.5 \mathrm{ml}$ microcentrifuge tubes containing a few crystals of phenylthiourea to prevent melanisation. After removal of haemocytes by centrifugation at $12000 \mathrm{~g}$ for $5 \mathrm{~min}$ at $4{ }^{\circ} \mathrm{C}$, the supernatant was lyophilized overnight.

\section{2. NMR Sample Preparation}

Extraction of metabolites from the hemolymph of $O$. nubilalis larvae was performed using a modified BlighDyer procedure, ${ }^{29}$ all lyophilizates were resuspended in a $500 \mu \mathrm{l}$ mixture of methanol, chloroform and water at a final ratio of 2.0:2.0:1.8. Samples were vortexed for $60 \mathrm{~s}$ and centrifuged at $10000 \mathrm{~g}$ for $10 \mathrm{~min}$ at $4{ }^{\circ} \mathrm{C}$ and then polar extracts (upper layer) were removed and lyophilized. Dried polar extracts were resuspended in $90 \% \mathrm{H}_{2} \mathrm{O} / 10 \% \mathrm{D}_{2} \mathrm{O}$ (GOSS Scientific Instruments Ltd, Essex UK) prepared as $100 \mathrm{mM}$ phosphate buffer (pH 7.0), containing $0.5 \mathrm{mM}$ sodium 3-(trimethylsilyl)propionate-2,2,3,3-d4 (TMSP, Cambridge Isotope Laboratories) as an internal reference.

\section{2. 1. NMR Experiments and Data Processing}

A $500 \mathrm{MHz}$ Bruker spectrometer equipped with a cryogenically cooled probe was used for one-dimensional (1D) ${ }^{1} \mathrm{H}$ and two-dimensional (2D) ${ }^{1} \mathrm{H} J$-resolved NMR spectra $(J-R E S)^{30}$ NMR data acquisition. In both cases, water resonance was suppressed using excitation sculpting. ${ }^{31}$ 1D spectra were acquired using a $90^{\circ}$ pulse, with $5 \mathrm{kHz}$ spectral width, a relaxation delay of $3 \mathrm{~s}$ and 128 transients. For quantitative analysis, 1D spectra were also acquired using a $30^{\circ}$ pulse and a relaxation delay of $15 \mathrm{~s}$. $2 \mathrm{D} J$-RES spectra were collected using a double spin echo sequence with 16 transients per increment and 32 increments. Strong coupling artefacts were suppressed by phase cycling. ${ }^{32} \mathrm{Be}-$ fore Fourier transformation, 2D J-RES spectra were multiplied by a combined sine-bell/exponential window function in the direct dimension and by a sine bell function in the incremented dimension. ${ }^{33}$ Skyline projections were calculated and spectra were aligned. Selected signals arising from residual solvents, and TMSP were excluded. Spectra were normalized according to probabilistic quotient normalization factors and binned at $0.005 \mathrm{ppm}$ (4 data points). The generalized-log transformation was applied before conducting multivariate statistical analysis. ${ }^{34}$ 
Spectra of the polar fraction were recorded with a simple $1 \mathrm{D}$ pulse sequence using a $60^{\circ}$ flip angle, 512 transients and 8 steady state scans, a relaxation delay of $3 \mathrm{~s}$, a spectra width of $7002 \mathrm{~Hz}$ and 32,768 data points. Data were processed by multiplying free induction decays by an exponential line broadening function of $0.5 \mathrm{~Hz}$ before Fourier transformation.

NMR data was processed using NMRLab in the MATLAB (The MathWorks, Inc., Natick, MA) programming environment. ${ }^{35}$ Multivariate statistical analysis of the projected $J$-RES NMR spectroscopy data was carried out using PLS toolbox 4.1 (Version 4.1; Eigenvector Research, Manson, WA). NMR resonances of metabolites were assigned using the Chenomx NMR Suite (version 5.0; Chenomx Inc., Edmonton, Canada).

\section{Results and Discussion}

In recent years, the number of metabolomic studies of insect biochemistry and diapause has been gradually increasing. ${ }^{19-25}$ The present study descibes appli- cation of NMR-based metabolomics to characterise molecular and biochemical changes underlying diapause in the European corn borer Ostrinia nubilalis. We compared metabolomic profiles in polar hemolymph extracts of diapausing and non-diapausing larvae of $O$. nubilalis using high-resolution 1H-NMR spectroscopy, and show that diapause, as a special state of physiological dormancy, has a different metabolomic fingerprint compared to active non-diapausing phase. Furthermore, different metabolic profiles was measured in diapausing larvae maintained at $5{ }^{\circ} \mathrm{C}$ vs. those gradually chilled to $-3{ }^{\circ} \mathrm{C}$ and $-16{ }^{\circ} \mathrm{C}$ and kept for two weeks. In total, 13 metabolites were identified (Fig. 1) including: 7 amino acids, glycerol, lactate, putrescine, acetate, citrate and succinate.

Principal component analysis (PCA) was conducted on ${ }^{1} \mathrm{H}-\mathrm{NMR}$ spectra of metabolites extracted from 4 groups of $O$. nubilalis larvae: 1 non-diapausing and 3 diapausing $\left(5{ }^{\circ} \mathrm{C},-3{ }^{\circ} \mathrm{C}\right.$ and $\left.-16{ }^{\circ} \mathrm{C}\right)$. The resulting PCA score plot (PC1 vs. $\mathrm{PC} 2)$ is shown in Fig. 2. The first two principal components capture $93.9 \%$ of the variance in the data. This PCA plot shows excellent separation between

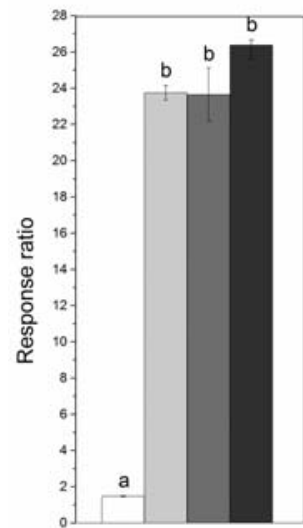

Lactate

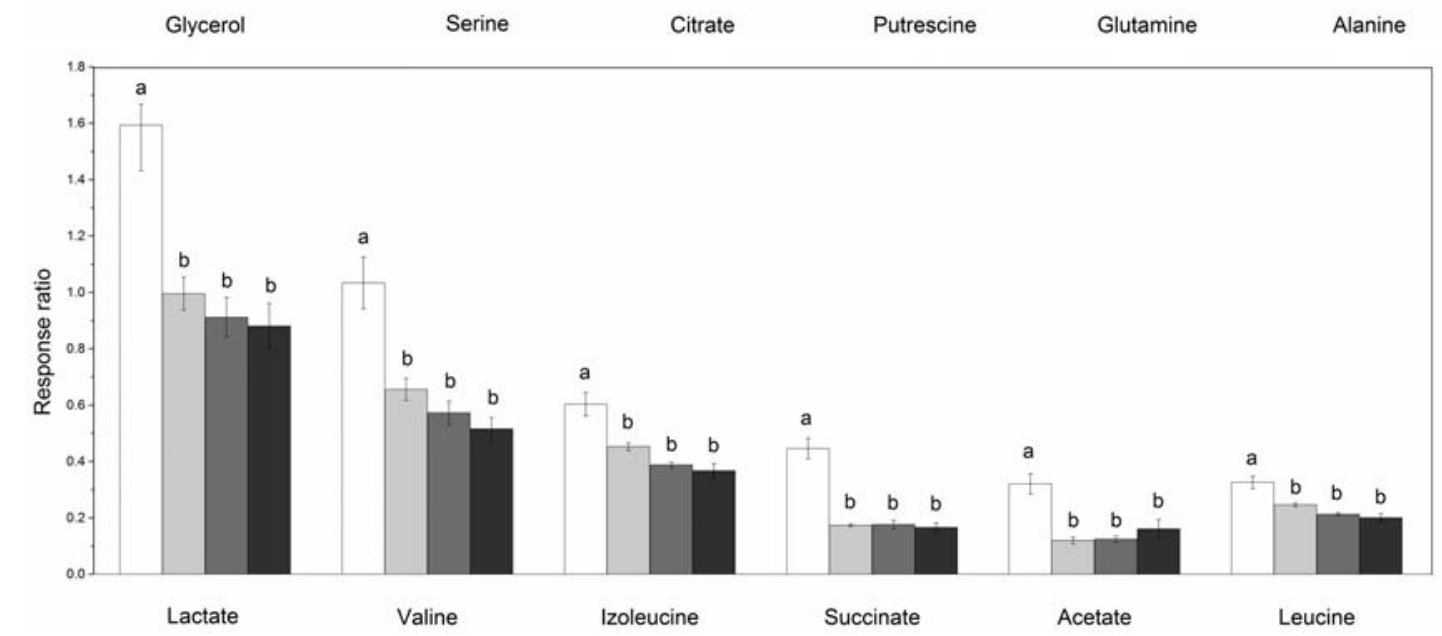

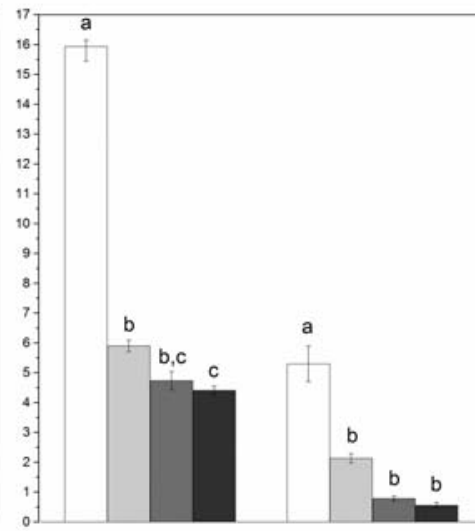

Citrate
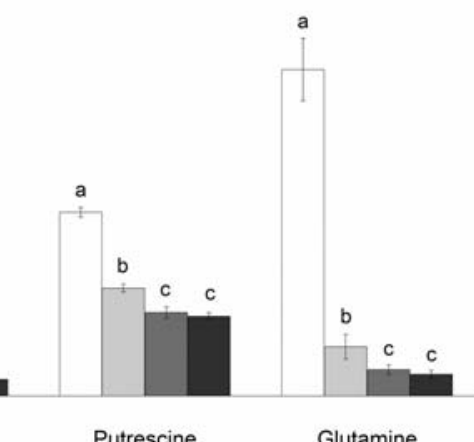

Glutamine

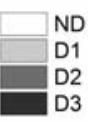

\section{ND \\ D3}
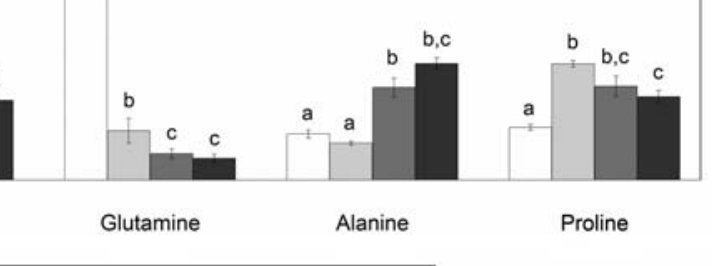

roline

Fig. 1. Metabolites altered during diapause and cold hardening in Ostrinia nubilalis larvae, analyzed by $1 \mathrm{H}-\mathrm{NMR}$ spectroscopy. Polar fraction of metabolites extracted from hemolymph of non-diapausing (ND) and diapausing (D) Ostrinia nubilalis larvae. Diapausing larvae were exposed to different temperatures D1 $\left(5^{\circ} \mathrm{C}\right)$, D2 $\left(-3{ }^{\circ} \mathrm{C}\right)$ and D3 $\left(-16^{\circ} \mathrm{C}\right)$. Error bars represent the standard error mean of five biological replicates. Letters shared in common between or among the groups indicate no significant difference (one-way ANOVA; post-hoc Tuckey test, p<0.05). 
non-diapausing and diapausing states in the first principal component, which explains the largest percentage $(89.5 \%)$ of the data.

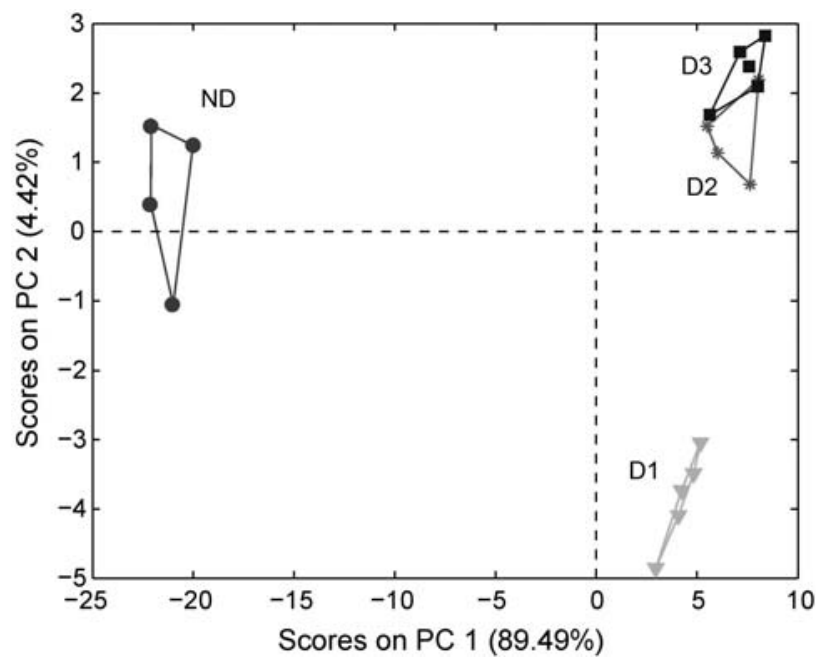

Fig. 2. Principal component analysis (PCA) scores plot (PC1 vs. PC2) of ${ }^{1} \mathrm{H}-\mathrm{NMR}$ spectra acquired on the polar fraction of metabolites extracted from the hemolymph of non-diapausing (ND) and diapausing (D) Ostrinia nubilalis larvae. Diapausing larvae were exposed to different temperatures as follows: D1 $\left(5^{\circ} \mathrm{C}\right), \mathrm{D} 2\left(-3^{\circ} \mathrm{C}\right)$ and D3 $\left(-16^{\circ} \mathrm{C}\right)$.

A typical ${ }^{1} \mathrm{H}-\mathrm{NMR}$ spectrum showing the most relevant discriminatory metabolites in the polar fraction of hemolymph from diapausing (positive loadings) and nondiapausing (negative loadings) larvae is shown in Fig. 3. A section of the loadings plot $(0.8-4.3 \mathrm{ppm})$ for the first

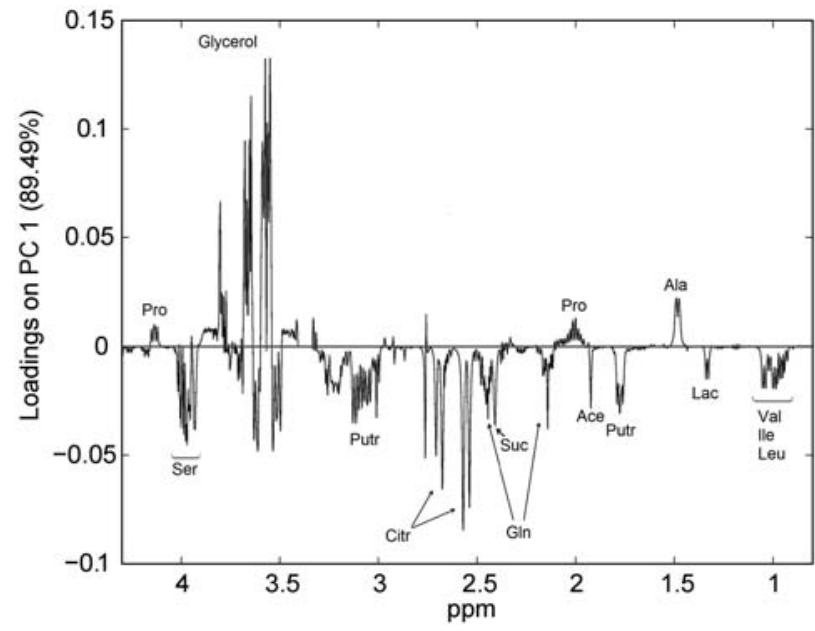

Fig. 3. Section of the loadings plot $(0.8-4.3 \mathrm{ppm})$ for the first principal component. Signals representing the most relevant discriminatory metabolites between diapausing (positive loadings) and non-diapausing (negative loadings) Ostrinia nubilalis larvae are shown (Val, valine; Ile, isoleucine; Leu, leucine; Lac, lactate; Ala, alanine; Putr, putrescine; Ace, acetate; Pro, proline; Suc, succinate; Gln, glutamine; Citr, citrate; Ser, serine). principal component is presented. As can be seen, the most dominant metabolites observed in the hemolymph polar fraction from diapausing larvae were glycerol, and to a lesser extent the amino acids proline and alanine. The major metabolites observed in hemolymph extract from non-diapausing larvae were the amino acids serine and glutamine, as well as several amino acids with aliphatic side chains: valine, leucine and isoleucine. In addition, levels of citrate, acetate, succinate, putrescine and lactate were found to be significantly increased in the non-diapausing group.

Among polar fraction metabolites extracted from the hemolymph of diapausing larvae, clear separation was observed by PCA analysis between larvae incubated at 5 ${ }^{\circ} \mathrm{C}$ and those kept at $-3{ }^{\circ} \mathrm{C}$ and $-16{ }^{\circ} \mathrm{C}$ (Fig. 4). The first two principal components shown on this plot explain $68.9 \%$ of the variation.

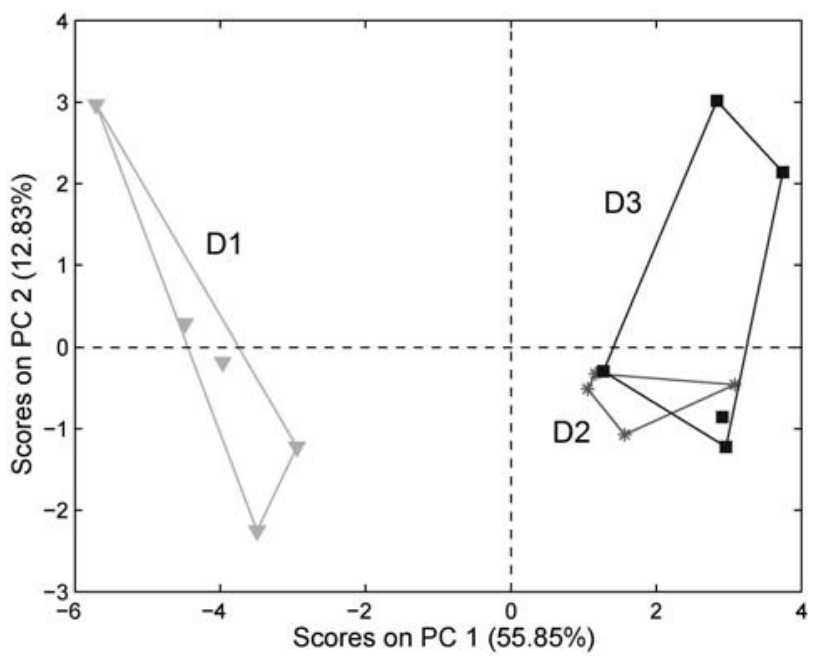

Fig. 4. Principal component analysis (PCA) scores plot (PC1 vs. $\mathrm{PC} 2)$ of ${ }^{1} \mathrm{H}-\mathrm{NMR}$ spectra acquired on the polar fraction of metabolites extracted from the hemolymph of diapausing (D) Ostrinia nubilalis larvae exposed to three different temperatures D1 $\left(5^{\circ} \mathrm{C}\right), \mathrm{D} 2$ $\left(-3{ }^{\circ} \mathrm{C}\right)$ and $\mathrm{D} 3\left(-16^{\circ} \mathrm{C}\right)$.

The most relevant discriminatory metabolites between diapausing groups kept at $5{ }^{\circ} \mathrm{C}$ (negative loadings) versus those incubated at $-3{ }^{\circ} \mathrm{C}$ and $-16^{\circ} \mathrm{C}$ (positive loadings) are shown in Fig. 5. A section of the loadings plot (0.8-4.3 ppm) for the first principal component is presented. Alanine, glycerol and acetate were found to be dominant in the metabolic profile of hemolymph extracted from diapausing larvae exposed to low temperatures $\left(-3{ }^{\circ} \mathrm{C}\right.$ and $\left.-16{ }^{\circ} \mathrm{C}\right)$. The metabolic profile of larvae exposed to $5{ }^{\circ} \mathrm{C}$ suggest that the major metabolites present in hemolymph extracts were proline, serine, putrescine, citrate, glutamine, lactate, valine, leucine and isoleucine.

Results from the present study are in agreement with earlier reports suggesting that freeze tolerant diapausing $O$. nubilalis larvae accumulate glycerol as a primary cryo- 


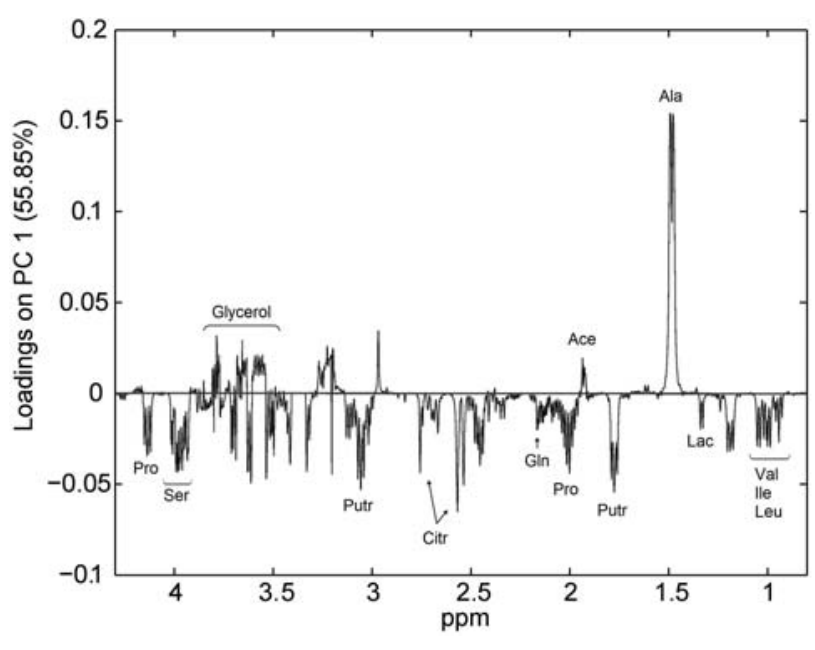

Fig. 5. Section of the loadings plot $(0.8-4.3 \mathrm{ppm})$ for the first principal component. Signals representing the most relevant metabolites which discriminate diapausing Ostrinia nubilalis larvae exposed to $5{ }^{\circ} \mathrm{C}$ (negative loadings) from those exposed to $-3{ }^{\circ} \mathrm{C}$ and $-16{ }^{\circ} \mathrm{C}$ (positive loadings) are shown (Val, valine; Ile, isoleucine; Leu, leucine; Lac, lactate; Ala, alanine; Putr, putrescine; Ace, acetate; Pro, proline; Gln, glutamine; Citr, citrate; Ser, serine).

protectant in high concentrations (Fig. 3). ${ }^{28,36}$ Furthermore, the present study indicates that free amino acids alanine and proline are higher in diapausing larvae than in nondiapausing larvae (Fig. 3). Glycerol is the most common cryoprotectant in insects, which, together with other similarly acting metabolic compounds, is associated with a colligative depression of the freezing point, and protects cells by stabilizing membranes and macromolecules. ${ }^{37-39}$ The correlation between increased concentrations of alanine and cold tolerance has been reported for a large number of insect species. ${ }^{9,22}$ In support of this, the colligative effectiveness of alanine is roughly the same as that of glycerol. ${ }^{19}$ Moreover, alanine is a less toxic end product of pyruvate catabolism than lactate, which may be important during diapause when the aerobic portion of cellular respiration is slowed. ${ }^{40}$

The increased level of proline observed in diapausing larvae is likely a consequence of accumulated alanine that is transformed to proline during diapause, as described in diapausing eggs of the silkworm Bombyx mori. ${ }^{41}$ Proline itself is a natural cryoprotectant expressed by numerous organisms under low-temperature stress: primarily in plants, but in some bacteria, invertebrates, protozoa, and algae as well. ${ }^{42}$ Besides alanine and proline, our NMR spectra suggest considerable involvement of other free amino acids (serine, glutamine, valine, leucine, isoleucine) in the main metabolic pathways of non-diapausing vs. diapausing larvae (Fig. 3).

Insect hemolymph is a dynamic and highly complex mixture of small molecular mass compounds like polyols, sugars, free amino acids, inorganic salts and variety of metabolic intermediates. Its composition varies conside- rably during development and stress exposure. Non-diapausing larvae were collected in the fifth instar, a developmental stage that is characterized by completion of food intake and preparation for pupariation. Thus, the increased content of free amino acids in the hemolymph in this period is probably due to their future use as building blocks for biosynthesis of new proteins or other nitrogencontaining compounds during metamorphosis. The increased levels of lactate, acetate and succinate (Fig. 3) observed in this study is consistent with high lipid and carbohydrate catabolism that match the cellular energy demands of actively developing larvae.

We observed clear separation in the PCA plot for metabolites from diapausing larvae reared at $5{ }^{\circ} \mathrm{C}$ vs. those kept at $-3{ }^{\circ} \mathrm{C}$ and $-16{ }^{\circ} \mathrm{C}$ (Fig. 4), indicating different metabolic profiles and suggesting that low temperatures have a significant influence on the larval metabolome. Since $O$. nubilalis larvae develop cold hardiness during diapause it is very difficult to distinguish the effects of thermal adaptation from the effects of diapause. The most dominant metabolite observed in hemolymph during diapause at subzero temperatures was alanine (Fig. 5). Alanine is, together with lactate, a well known end-product of anaerobic metabolism in many terrestrial insects; and could be produced from pyruvate in a one step transamination reaction. However, as reactions are readily reversible, another possibility is that up-regulation of alanine could be part of the intermediary metabolism of glycerol biosynthesis.

Along with alanine, glycerol and acetate were elevated in diapausing larvae kept at subzero temperatures (Fig. 5). Both glycerol and acetate could also accumulate during the anaerobic metabolism phase which is probably predominant at low temperatures. In general, the end products of anaerobic metabolism are mostly unknown for many insect species, including $O$. nubilalis. For example, Drosophila melanogaster produces lactate, alanine and acetate, but in other species a wide array of other products have been identified, including: sorbitol, succinate, glycerol, $\alpha$-glycerol-3-phosphate, pyruvic acid, and fatty acids. ${ }^{43}$ Acetate could be produced from mitochondrial acetyl-CoA in the absence of oxygen or via alternative pathways. $^{43}$

Discriminatory metabolites in hemolymph which separate diapausing larvae exposed to $5{ }^{\circ} \mathrm{C}$ from those exposed to subzero temperatures were similar to those obtained when comparing non-diapausing and diapausing larvae, although concentrations were different (Fig. 5). The absence of succinate could be consistent with slowed aerobic respiration during diapause. Interestingly, the polyamine putrescine was found to discriminate non-diapausing from diapausing larvae, and diapausing larvae kept at $5{ }^{\circ} \mathrm{C}$ from diapausing larvae kept at subzero temperatures. This is a novel finding for this species and suggests a need for further research. Elevations of putrescine levels has been associated with stress in plants, earthworms, nema- 
todes, leeches and planarians. ${ }^{22,44,45}$ In animals, the conversion of arginine to putrescine occurs via ornithine via arginase and ornithine decarboxylase. Since, arginine and ornitine are part of the urea cycle, whose presence in insects has not been confirmed, the origin of putrescine in hemolymph of $O$. nubilalis remains unclear. The primary excretory product of the catabolism of nitrogen compounds, nucleic acids and proteins in insects is uric acid and urea is present only in trace amounts. Our results do not suggest changes in the concentration of urea, although the level of this metabolite does correlate with cold hardiness in some insects. ${ }^{22}$ However, putrescine and its derivatives, spermine and spermidine are regulatory molecules that play important roles in basic genetic processes, such as DNA synthesis and gene expression. ${ }^{46}$ Putrescine has been shown to modulate the action of juvenile hormone during neural development in crickets. ${ }^{47}$ The potential physiological role of putrescine in $O$. nubilalis larvae remains an open question.

\section{Conclusions}

Results from the present study strongly suggest that distinct metabolomes function in actively developing versus diapausing larvae: metabolism is suppressed during diapause and, due to a decline in respiration and oxidative metabolism, is diverted to anaerobic processes, especially during exposure to subzero temperatures. The present study provides new insight into mechanisms of cold resistance and diapause in $O$. nubilalis and suggest areas requiring future research, such as the role of polyamines in diapause. Moreover, based on our results, ${ }^{1} \mathrm{H}-\mathrm{NMR}$ spectroscopy may be a useful and reliable method for studying insect metabolomes.

\section{Acknowledgements}

This work was funded by the Ministry of Science and Technological Development, Republic of Serbia, grant 173014 "Molecular mechanisms of redox signalling in homeostasis: adaptation and pathology". The authors thank the Wellcome Trust and the EU in the context of the EU-NMR grant (RII3-026145) for supporting the HWBNMR facility in Birmingham. The authors thank the EU for supporting S.T. in the context of the MOTET Marie Curie project. We thank Dr. Edward Petri for editing this manuscript for English grammar and content.

\section{References}

\footnotetext{
1. V. Košt'ál, J. Insect Physiol. 2006, 52, 113-127. http://dx.doi.org/10.1016/j.jinsphys.2005.09.008

2. C. B. Huffaker, A. P. Gutierrez: Ecological Entomology,
}

John Wiley and Sons Ltd, Chichester, UK, 1999, pp. 159200.

3. D. S. Saunders: Insect Clocks, Elsevier, Amsterdam, NL, 2002, pp. 271-338. http://dx.doi.org/10.1016/B978-044450407-4/50010-0

4. D. L. Denlinger, G. D. Yocum, J. P. Rinehart, in: K. I. Gilbert, K. Latrou, S. S. Gill (Ed): Hormonal control of diapause in Comprehensive Molecular Insect Science, Elsevier, Amsterdam, NL, 2005, pp. 615-648. http://dx.doi.org/10.1016/B0-44-451924-6/00043-0

5. R. D. Flannagan, S. P. Tammariello, K. H. Joplin, R. A. Cikra-Ireland, G. D. Yocum, D. L. Denlinger, Proc. Natl. Acad. Sci. USA 1998, 95, 5616-5620. http://dx.doi.org/10.1073/pnas.95.10.5616

6. D. L. Denlinger, Annu. Rev. Entomol. 2002, 47, 93-122. http://dx.doi.org/10.1146/annurev.ento.47.091201.145137

7. T. H. MacRae, Cell. Mol. Life Sci. 2010, 67, 2405-2424. http://dx.doi.org/10.1007/s00018-010-0311-0

8. D. L. Denlinger, in: R. E. Lee, Jr., D. L. Denlinger, (Ed): Relationship between cold hardiness and diapause in Insects at Low Temperature, Chapman and Hall, New York, USA, 1991, pp. 174-198. http://dx.doi.org/10.1007/978-1-4757-0190-6_8

9. M. Goto, Y. Sekine, H. Outa, M. Hujikura, K. Suzuki, J. Insect Physiol. 2001, 47, 157-165. http://dx.doi.org/10.1016/S0022-1910(00)00099-8

10. A. S. Pullin, Eur. J. Entomol. 1996, 93, 121-129.

11. W. Block, Phil. Trans. R. Soc. Lond. B 1990, 326, 613-633. http://dx.doi.org/10.1098/rstb.1990.0035

12. G. Grubor-Lajšić, E.T. Petri, D. Kojić, J. Purać, Ž. D. Popović, M. R. Worland, M. S. Clark, M. Mojović, D. P. Blagojević, Arch. Insect Biochem. Physiol. 2013, 82, 59-70. http://dx.doi.org/10.1002/arch.21073

13. J. H. Crowe, L. M. Crowe, J. F. Carpenter, A. S. Rudolph, C. A. Wistrom, B. I. Spargo, T. J. Anchordoguy, Biochem. Biophys. Acta. 1988, 947, 367-384. http://dx.doi.org/10.1016/0304-4157(88)90015-9

14. K. B. Storey, J. M. Storey, in R. E. Lee, Jr., D. L. Denlinger (Ed): Biochemistry of cryoprotectants, in: Insects at Low Temperature, Chapman and Hall, New York, USA, 1991, pp. 64-93. http://dx.doi.org/10.1007/978-1-4757-0190-6_4

15. K. B. Storey, J. M. Storey, Can. J. Zool. 2012, 90, 456-475.

16. M. S. Clark, M. S. Thorne, J. Purać, G. Grubor-Lajšić, M. Kube, R. Reinhardt, M. R. Worland, BMC Genomics 2007, 8, e475. http://dx.doi.org/10.1186/1471-2164-8-475

17. M. S. Clark, M. S. Thorne, J. Purać, G. Burns, G. Hillyard, Ž. D. Popović, G. Grubor-Lajšić, M. R. Worland, BMC Genomics 2009, 10, e328. http://dx.doi.org/10.1186/1471-2164-10-328

18. J. Purać, G. Burns, M. S. Thorne, G. Grubor-Lajšić, M. R. Worland, M. S. Clark, J. Insect Physiol. 2008, 54, 13561362. http://dx.doi.org/10.1016/j.jinsphys.2008.07.012

19. M. R. Michaud, D. L. Denlinger, J. Comp. Physiol. B 2007, 177, 753-763. http://dx.doi.org/10.1007/s00360-007-0172-5

20. J. Overgaard, A. Malmendal, J. G. Sørensen, J. G. Bundy, V. 
Loeschcke, N.C. Nielsen, M. Holmstrup, J. Insect Physiol. 2007, 53, 1218-1232.

http://dx.doi.org/10.1016/j.jinsphys.2007.06.012

21. T. C. Hawes, A. C. Hines, M. R. Viant, J. S. Bale, M. R. Worland, P. Convey, CryoLetters 2008, 29, 505-515.

22. M. R. Michaud, J. B. Benoit, G. López-Martínez, M. A. Elnitsky, R. E. Lee, Jr., D. L. Denlinger, J. Insect Physiol. 2008, 54, 645-655.

http://dx.doi.org/10.1016/j.jinsphys.2008.01.003

23. C. Phalaraksh, S. E. Wilson, E. M. Lenz, J. K. Nicholson, J. C. Lindon, ScienceAsia 2008, 34, 279-286. http://dx.doi.org/10.2306/scienceasia1513-1874.2008.34.279

24. H. Colinet, D. Renault, B. Guével, E. Com, PLoS ONE 2012, 72, e32606. http://dx.doi.org/10.1371/journal.pone.0032606

25. N. M. Teets, J. T. Peyton, G. J. Ragland, H. Colinet, D. Renault, D. A Hahn, D. L. Denlinger, Physiol. Genomics 2012, 44, 764-777. http://dx.doi.org/10.1152/physiolgenomics.00042.2012

26. H. Kitano, Science 2002, 295, 1662-1664. http://dx.doi.org/10.1126/science.1069492

27. J. G. Bundy, M. P. Davey, M. R. Viant, Metabolomics 2009 , 5, 3-21. http://dx.doi.org/10.1007/s11306-008-0152-0

28. G. Grubor-Lajšić, W. Block, M. R. Worland, Physiol. Entomol. 1992, 17, 148-152. http://dx.doi.org/10.1111/j.1365-3032.1992.tb01192.x

29. H. Wu, A. D. Southam, A. Hines, M. R. Viant, Anal. Biochem. 2008, 372, 204-212. http://dx.doi.org/10.1016/j.ab.2007.10.002

30. W. P. Aue, J. Karhan, R. R. Ernst, J. Chem. Phys. 1976, 64, 4226-4227. http://dx.doi.org/10.1063/1.431994

31. T. L. Hwang, A. J. Shaka, J. Magn. Reson. A 1995, 112, 275-279. http://dx.doi.org/10.1006/jmra.1995.1047

32. M. J. Thrippleton, R. A. E. Edden, J. Keeler, J. Magn. Reson. 2005, 174, 97-109. http://dx.doi.org/10.1016/j.jmr.2005.01.012

33. S. Tiziani, A. Lodi, C. Ludwig, H. M. Parsons, M. R. Viant, Anal. Chim. Acta 2008, 610, 80-88.

http://dx.doi.org/10.1016/j.aca.2008.01.030
34. H. M. Parsons, C. Ludwig, U. L. Günther, M. R. Viant, $B M C$ Bioinformatics 2007, 8, e234. http://dx.doi.org/10.1186/1471-2105-8-234

35. U. L. Günther, C. Ludwig, H. Ruterjans, J. Magn. Reson. 2000, 145, 201-208. http://dx.doi.org/10.1006/jmre.2000.2071

36. G. Grubor-Lajšić, W. Block, M. Telesmanić, A. Jovanović, D. Stevanović, F. Bača. Arch. Insect Biochem. Physiol. 1997, $36,1-10$.

http://dx.doi.org/10.1002/(SICI)1520-6327(1997)36:1<1::AID -ARCH1>3.0.CO;2-\#

37. K. Gekko, J. Biochem. 1981, 90, 1633-1641.

38. K. B. Storey, J. M. Storey, Physiol. Rev. 1988, 68, 27-84.

39 V. Košt'ál, M. Slachta, P. Simek, Comp. Biochem. Physiol. B 2001, 130, 365-374.

http://dx.doi.org/10.1016/S1096-4959(01)00441-9

40. B. Bao, W. H. Xu, BMC Genomics 2011, 12, e224. http://dx.doi.org/10.1186/1471-2164-12-224

41. M. Osanai, Y. Yonezawa, Insect Biochem. 1986, 16, 373379. http://dx.doi.org/10.1016/0020-1790(86)90050-8

42. R. Z. Troitzsch, H.Vass, W. J. Hossack, G. J. Martyna, J. Crain, J Phys. Chem. B 2008, 112, 4290-4297.

http://dx.doi.org/10.1021/jp076713m

43. J. D. Feala, L. Coquin, A. D. McCulloch, G. Paternostro, Mol. Syst. Biol. 2007, 3, 99.

http://dx.doi.org/10.1038/msb4100139

44. K. Hamana, H. Hamana, T. Shinozawa, Comp. Biochem. Physiol. 1995, 111, 91-97. http://dx.doi.org/10.1016/0305-0491(94)00222-G

45. J. Renaut, L. Hoffmann, J. F. Hausman, Physiol. Plantarum 2005, 125, 82-94. http://dx.doi.org/10.1111/j.1399-3054.2005.00554.x

46. J. Janne, L. Alhonen, M. Pietila, T. A. Keinanen, Eur. J. Biochem. 2004, 271, 877-894. http://dx.doi.org/10.1111/j.1432-1033.2004.04009.x

47. M. Cayre, C. Strambi, P. Charpin, R. Augier, A. Strambi, Proc. Natl. Acad. Sci. USA 1997, 94, 8238-8242. http://dx.doi.org/10.1073/pnas.94.15.8238

\section{Povzetek}

Jedrska magnetna resonanca (NMR) je pomembna metabolomska tehnika, ki omogoča pregled nad številnimi spojinami hkrati. V tej študiji smo uporabili 1H-NMR metabolomski pristop, da bi raziskali, kako ličinke evropske koruzne vešč (Ostrinia nubilalis) vstopajo v diapavzo in v obdobje hladne trdnosti. Povezava med diapavzo in hladno trdnostjo te vrste je slabo raziskana, še posebej na metabolomski ravni. Zato smo primerjali metabolomske vzorce v polarnih ekstraktih hemolimf pri ličinkah $O$. nubilalis, ki so ali niso prešle v diapavzo. Rezultati so pokazali, da ima diapavza, kot mirujoče stanje, drugačen metabolomski vzorec v primerjavi z aktivno fazo, kjer diapavze ni. Poleg tega smo opazili razlike pri diapavzi ličink, ki so bile za dva tedna ohlajene od $5{ }^{\circ} \mathrm{C}$ do $-3{ }^{\circ} \mathrm{C}$ ali do $-16{ }^{\circ} \mathrm{C}$. Obe skupini je med seboj ločevalo 13 metabolitov: sedem aminokislin, glicerol, acetat, citrat, sukcinat, laktat in putrescin. 1H-NMR spektroskopija je dala nov vpogled v metabolomiko hladne odpornosti in diapavze $O$. nubilalis in nakazala na različne metabolome pri aktivno razvijačih ličinkiah in tistih v diapavzi. 